\title{
Gold(I)-catalyzed formation of furans by a Claisen- type rearrangement of ynenyl allyl ethers
}

Florin M. Istrate and Fabien Gagosz

\author{
Letter \\ Address: \\ Département de Chimie, UMR 7652, CNRS/Ecole Polytechnique, \\ 91128 Palaiseau, France

\section{Email:} \\ Fabien Gagosz* - gagosz@dcso.polytechnique.fr \\ * Corresponding author \\ Keywords: \\ Claisen rearrangement; furans; gold-catalysis; quaternary centers
}

\author{
Beilstein J. Org. Chem. 2011, 7, 878-885. \\ doi:10.3762/bjoc. 7.100 \\ Received: 20 April 2011 \\ Accepted: 08 June 2011 \\ Published: 29 June 2011 \\ This article is part of the Thematic Series "Gold catalysis for organic \\ synthesis". \\ Guest Editor: F. D. Toste
}

(c) 2011 Istrate and Gagosz; licensee Beilstein-Institut.

License and terms: see end of document.

\begin{abstract}
A series of ynenyl allyl ethers were rearranged into polysubstituted furans in the presence of a gold(I) catalyst. It is proposed that the transformation involves a Claisen-type rearrangement that allows the efficient creation of quaternary centers under mild experimental conditions.
\end{abstract}

\section{Findings}

Furans represent an important class of heteroaromatic compounds, which are found in a large number of natural products, in synthetic biologically active substances and also in flavor chemicals [1,2]. Consequently, many efforts have been devoted to the development of synthetic methods which allow a rapid, efficient, and selective access to the furan motif [3-6]. Recently, several new strategies that involve a metal-mediated cyclization of an allene or an alkyne derivative with an oxygen functionality have appeared in the literature [7]. Among the transition metals that are commonly employed in these transformations (viz. $\mathrm{Cu}, \mathrm{Ag}, \mathrm{Pd}$ and $\mathrm{Au}$ ), gold has proven to be particularly suitable given the strong $\pi$ Lewis acidic property of cationic gold species and their ability to activate alkynes and allenes towards the addition of oxygen functionalities [8-16].
The various alkynyl and allenyl compounds presented in Scheme 1 have thus proved to be suitable precursors for the formation of polysubstituted furans in the presence of a gold(I) or a gold(III) catalyst [17-44].

We report herein our own investigations in this field which have led to the development of a new procedure for the synthesis of polysubstituted furans by a gold-catalyzed cycloisomerization of ynenyl allyl ethers [45-48].

In the course of our work on the development of new goldcatalyzed transformations [49-51], we recently found that a series of ynenyl allyl tosylamides 1 ( $\mathrm{X}=\mathrm{NTs}$ ) could be converted under mild experimental conditions into functional- 
<smiles>[R]C#CCC([R1])=O</smiles><smiles>[R]C=C=CC([R])=O</smiles><smiles>[R]C#CC1([R])OC1C[R]</smiles><smiles>[R]C#CC1(C([R])=O)CC1[R]</smiles><smiles>[R]C#CCOC([R])=CC([R])=O</smiles><smiles>[R]C#CC1([R])C2[R]C1O2</smiles>

$\mathrm{R}^{3}$<smiles>[R]C(=O)C([R2])(C#CC)OC(C)=O</smiles><smiles>[R]C#CC([R])([R])CC([R])=O</smiles><smiles>[R]C#C/C(=C/[R])C([R1])O</smiles><smiles>[R]C#CC(=C[R])C([R1])=O</smiles><smiles>[R]C#CC([R3])=C([R])C([R])O</smiles><smiles>[R]C#CC([R])(O)C([R])O</smiles>

$[\mathrm{Au}]$<smiles>[R]c1oc([R])c([R])c1[R]</smiles>

Scheme 1: Alkynyl and allenyl substrates in gold-catalyzed formation of furans.

ized pyrroles $3(\mathrm{X}=\mathrm{NTs})$ in the presence of a gold(I) catalyst (Scheme 2) [52]. In contrast to Fürstners observations for the rearrangement of allyl pent-4-ynyl ethers [53,54], the results obtained during this study strongly suggested that no allyl cation was formed during the reaction. The substitution pattern of the pyrroles thus obtained point toward the involvement of a more concerted aza-Claisen-type rearrangement mechanism (2 $\rightarrow \mathbf{3}$ ) and tend to exclude the possibility of a simple $\mathrm{N}$ to $\mathrm{C}$ allyl shift ( $\mathbf{2} \rightarrow \mathbf{4} \rightarrow \mathbf{5}$ ). Based on these initial findings, we envisaged that an analogous transformation could be employed for the synthesis of substituted furans $3(\mathrm{X}=\mathrm{O})$ from ynenyl allyl ethers $1(X=O)$ (Scheme 2). The proof that a similar reaction can take place via an analogous pathway using oxygen- instead of nitrogen-derivatives would therefore support our initial mechanistic proposal and would broaden the scope of this new gold-catalyzed Claisen-type rearrangement [55-62].
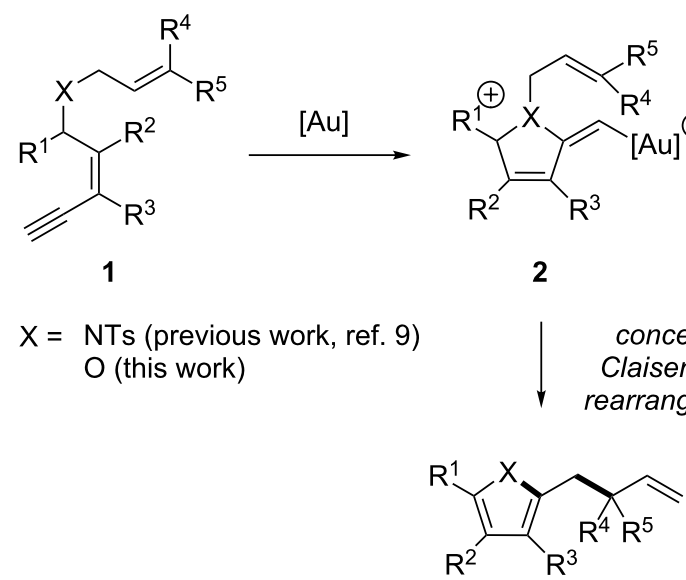

3

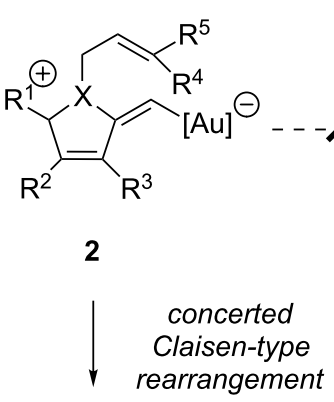

3<smiles>[R]C([R])=CCCc1[X]c([R])c([R])c1[R]</smiles> 
Moreover this synthetic approach to furans would be particularly interesting for several reasons:

- The required ynenyl allyl ether substrates are easily accessible via various methods (see Supporting Information File 1 for more details),

- the Claisen-type rearrangement would allow the formation of two new $\mathrm{C}-\mathrm{O}$ and $\mathrm{C}-\mathrm{C}$ bonds in a single step,

- the reaction would allow the easy formation of quaternary centers and the introduction of a variety of other substituents on the side chain (when $R^{4} \neq H$ and $R^{5} \neq H$ ),

- and the reaction could be particularly useful for the preparation of 2-butenylfurans, whose motif can be found in a variety of natural products, such as rubifolide [63], curzerene [64] or pumiloxide [65] (Figure 1).

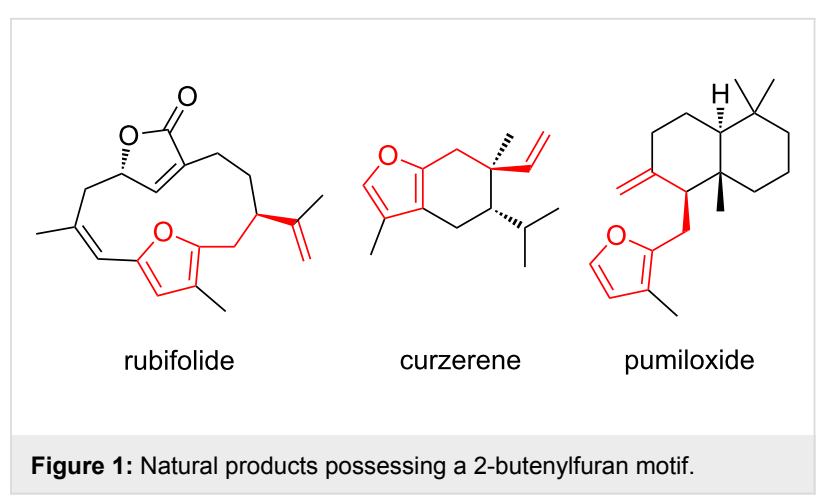

Thus, a wide range of ynenyl allyl ethers $\mathbf{6 a}-\mathbf{s}$ was synthesized (see Supporting Information File 1) and reacted under the conditions that were found to be optimal for the analogous formation of pyrroles from ynenyl allyl tosylamides, that is, $2 \mathrm{~mol} \%$ of the gold catalyst $\left\{\left[\left(p-\mathrm{CF}_{3}-\mathrm{C}_{6} \mathrm{H}_{4}\right)_{3} \mathrm{P}\right]-\mathrm{Au}-\mathrm{NTf}_{2}\right\}$ [66] in dichloromethane at room temperature (Table 1).

Table 1: Scope of the gold(I)-catalyzed formation of furans. ${ }^{a}$<smiles>[R]C([R])=CCOC([R7])C([R])=C([R])C#C</smiles>

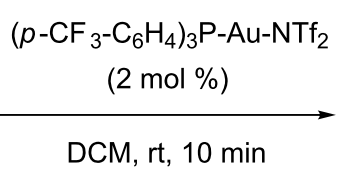

DCM, rt, $10 \mathrm{~min}$

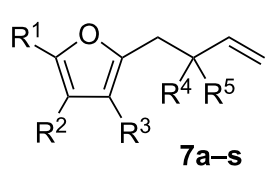

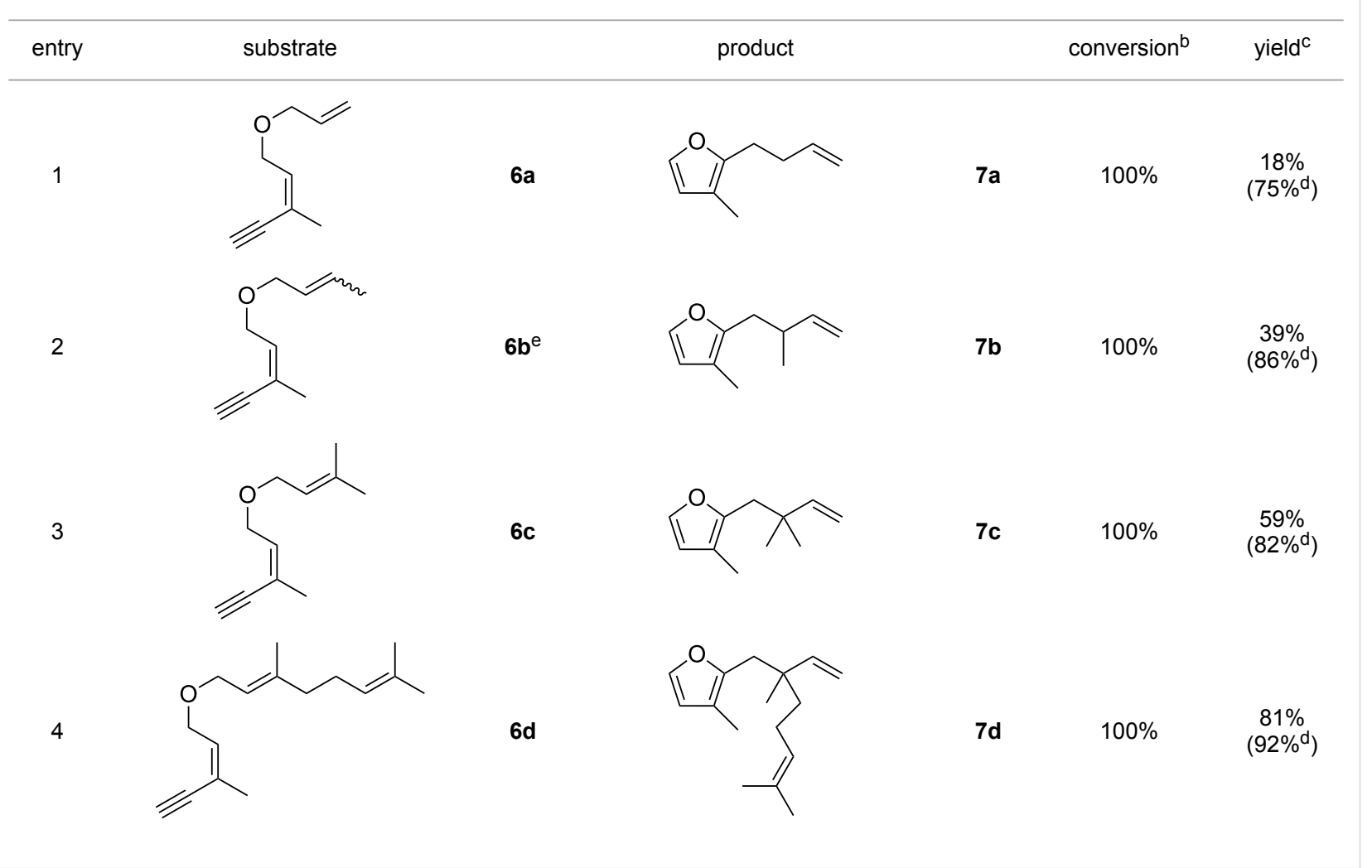


Beilstein J. Org. Chem. 2011, 7, 878-885.

Table 1: Scope of the gold(I)-catalyzed formation of furans. ${ }^{a}$ (continued)

5<smiles>C#CC(C)=CCOCC=C(C)CCc1ccccc1</smiles>

$6 e^{f}$

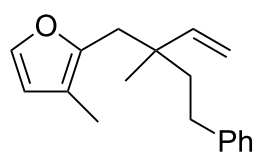

$6 f$

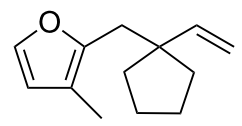

$6 \mathrm{~g}$

8

7<smiles>C#CC(C)=CCOCC=C1CCCCC1</smiles>

$6 h$

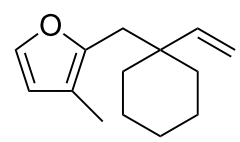

9<smiles>C#C/C(C)=C/C(CC)OCC=C(C)C</smiles>

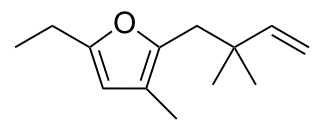

$6 i$

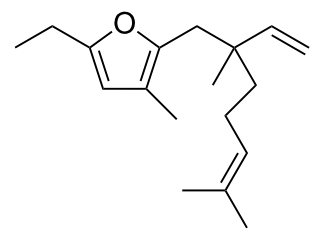

6j

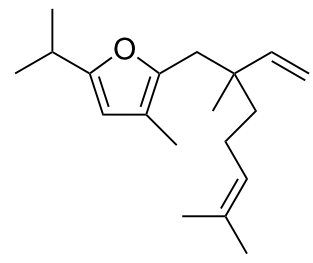

Gk
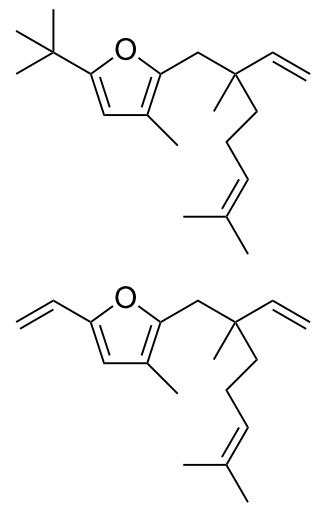

$7 \mathrm{~g}$

$7 e$

$100 \%$

$66 \%$

$7 f$

$100 \%$

$71 \%$

$7 h$

$100 \%$

quant.

Ti

quant.

7j

$100 \%$

$78 \%$

$7 k$

$100 \%$

$78 \%$

TI

$17 \%$

881 
Table 1: Scope of the gold(I)-catalyzed formation of furans. ${ }^{\text {a }}$ (continued)

13<smiles>C#C/C(C)=C/C(OC/C=C(\C)CCC=C(C)C)c1ccccc1</smiles>

14<smiles>C#C/C(=C\COC/C=C(\C)CCC=C(C)C)c1ccccc1</smiles>

15

16<smiles>C#C/C(=C\COCC=C1CCCCC1)c1ccccc1</smiles>

60

$6 p$

$6 q$<smiles>C=CC(C)(CCC=C(C)C)Cc1oc(C(C)C)cc1CCCCC</smiles>

$6 s$<smiles>C=CC1(Cc2occc2-c2ccccc2)CCCCC1</smiles><smiles>C=CC(C)(CCC=C(C)C)Cc1occc1CCCCC</smiles><smiles>C=CC1(Cc2occc2CCCCC)CCCCC1</smiles><smiles>C=CC(CCC=C(C)C)(CCC(=C)C)Cc1oc(-c2ccccc2)cc1C</smiles>

$7 m$

$100 \%$ $77 \%$<smiles></smiles>

$7 n$ $100 \%$ $80 \%$

7o $100 \%$ $90 \%$

$7 p$ $100 \%$ $82 \%$

$7 q$ $100 \%$ $86 \%$

$7 r$ $>84 \% \mathrm{~g}$ $73 \%$<smiles>C=CC1(Cc2oc(C(C)C)cc2CCCCC)CCCCC1</smiles>

$7 s$ $>62 \% \mathrm{~g}$

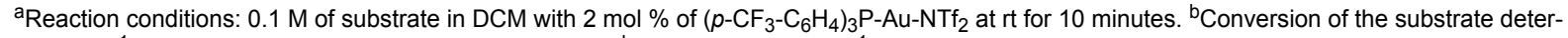

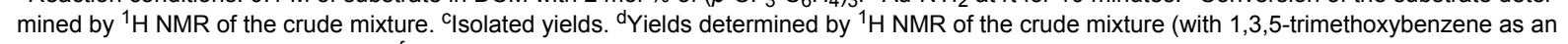
internal reference). ${ }^{\mathrm{e}} \mathrm{Z} / \mathrm{E}$ ratio $\approx 1 / 3 .{ }^{\mathrm{f}} \mathrm{Z} / \mathrm{E}$ ratio $\approx 1 / 2.6$. ${ }^{\mathrm{R}}$ Reaction time: 40 minutes.

Under these conditions, we observed the rapid formation (usually less than 10 minutes) of the expected furans. The allyl (6a), crotyl (6b), prenyl (6c) and geranyl (6d) derivatives were readily cycloisomerized in the presence of the gold catalyst, but the isolation of the corresponding furans $7 \mathbf{a}-\mathbf{d}$ proved to be quite challenging due to their high volatility (entries 1-4). These reactions were therefore performed in deuterated dichloromethane and their yields assessed by ${ }^{1} \mathrm{H}$ NMR spectroscopy with 1,3,5-trimethoxybenzene as an internal reference (75-92\%). All the examples presented in entries 2-19 are in 
agreement with the postulated Claisen-type rearrangement since only the exclusive formation of branched products of type $\mathbf{3}$ was observed. Indeed, a linear product of type $\mathbf{5}$ resulting from an $\mathrm{O}$ to $\mathrm{C}$ shift of the allylic moiety could not be detected, whatever substrate was used [67]. Substrates $\mathbf{6 b}$ and $\mathbf{6 e}$, which were used as a mixture of $Z / E$ isomers, each afforded a single product, i.e., the furans $7 \mathbf{b}$ and $7 \mathbf{e}$, respectively (entries 2 and 5). The cycloisomerization of compounds $6 \mathbf{6 f}, \mathbf{6 g}, \mathbf{6 0}, \mathbf{6 q}$ and $\mathbf{6 s}$, which possess an exocyclic allyl moiety, furnished the corresponding furans $7 \mathbf{f}, \mathbf{7 g}, \mathbf{7 o}, \mathbf{7 q}$ and $\mathbf{7 s}$ in moderate to quantitative yields (entries 6, 7, 15, 17 and 19). It is also worth noting that an increase in the substitution at the terminus of the allylic moieties of the substrates (monosubstitution in the case of $\mathbf{6 b}$, disubstitution for $\mathbf{6 c}-\mathbf{s}$ ) did not notably influence the conversion, the rate or the yield of the reaction, even though the steric hindrance of the postulated Claisen intermediate $\mathbf{2}$ would have increased. This behavior strongly contrasts with the generally less efficient Claisen reactions of similarly substituted substrates and consequently allows the easy creation of a new quaternary center for the disubstituted substrates $\mathbf{6} \mathbf{c}-\mathbf{s}$ (entries 3-19). Interestingly substrates $\mathbf{6} \mathbf{h}-\mathbf{m}$, which possess an extra substituent at the allylic position of the ynenyl fragment, also easily rearranged to afford the expected furans $7 \mathbf{h}-\mathbf{m}$ in good to quantitative yields (entries 8-13). A large variety of substituents were tolerated including primary, secondary or tertiary alkyl groups and even a vinyl or a phenyl group. However, a poor yield (17\%) was obtained when compound $\mathbf{6}$ was used as the substrate, due to the facile polymerization of the corresponding vinylfuran $7 \mathbf{l}$ (entry 12). Substituents other than a simple methyl group could be introduced at position $\mathrm{C}(3)$ of the furans.
Substrates $\mathbf{6 n}-\mathbf{q}$, which possess either a phenyl or a longer alkyl chain, were indeed efficiently converted into compounds $7 \mathbf{n}-\mathbf{q}(80-90 \%$, entries 14-17). However, limited reactivity was observed with ethers $\mathbf{6 r}-\mathbf{s}$, which could not be completely converted into the corresponding furans $7 \mathbf{r}-\mathbf{s}$ (entries 18-19).

A mechanistic proposal for the formation of furans $\mathbf{7 a}-\mathbf{s}$ is presented in Scheme 3. It is based on the results shown in entries 2-19 (Table 1), which support the involvement of a gold-catalyzed Claisen-type rearrangement as the key step of the transformation.

The gold(I) activation of the alkyne moiety in substrate 6 could promote the nucleophilic addition of the oxygen atom, and lead to the formation of the cationic vinyl gold intermediate $\mathbf{8}$. A subsequent Claisen-type rearrangement would furnish the intermediate 9. The loss of a proton to allow aromatization of the system, followed by a protodemetalation step would finally give furan 7.

In summary, we have developed a new gold(I)-catalyzed formation of polysubstituted furans, which is characterized by its efficiency, the mild conditions employed and the easy formation of quaternary centers. The selectivity observed in the structure of the final product is in agreement with the postulated Claisentype rearrangement. Further studies related to the development of an asymmetric version of this new gold(I)-catalyzed process and its application to the synthesis of natural products are underway.

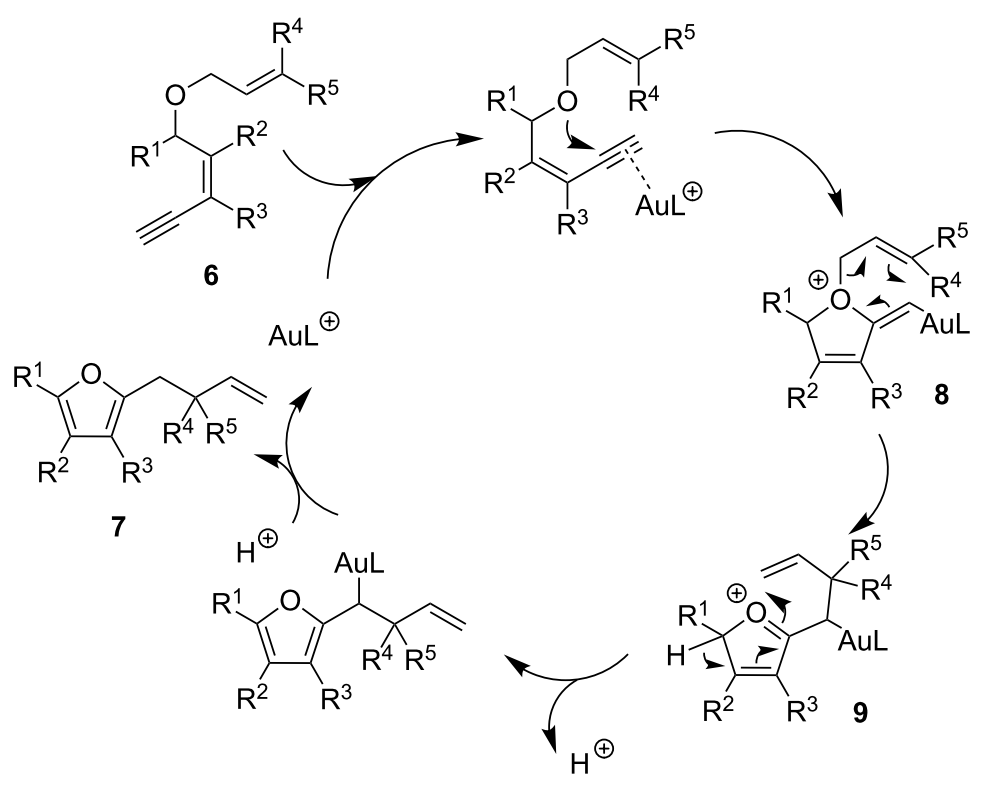




\section{Supporting Information}

\section{Supporting Information File 1}

Detailed experimental procedures.

[http://www.beilstein-journals.org/bjoc/content/

supplementary/1860-5397-7-100-S1.pdf]

\section{Supporting Information File 2}

NMR spectral data for substrates $\mathbf{6 a}-\mathbf{s}$.

[http://www.beilstein-journals.org/bjoc/content/

supplementary/1860-5397-7-100-S2.pdf]

\section{Supporting Information File 3}

NMR spectral data for products $\mathbf{7 a}-\mathbf{s}$.

[http://www.beilstein-journals.org/bjoc/content/

supplementary/1860-5397-7-100-S3.pdf]

\section{Acknowledgments}

We thank Prof. S. Z. Zard (CNRS / Ecole Polytechnique) for helpful discussions and Rhodia Chimie Fine for the donation of $\mathrm{HNTf}_{2}$.

\section{References}

1. Keay, B. A.; Dibble, P. W. In Comprehensive Heterocyclic Chemistry II, A Review of the Literature 1982-1995; Katritzky, A. R.; Rees, C. W.; Scriven, E. F. V., Eds.; Pergamon Press: Oxford, 1997; Vol. 2, pp 395-436.

2. Donnelly, D. M. X.; Meegan, M. J. Furans and their Benzo Derivatives: (iii) Snthesis and Application. In Comprehensive Heterocyclic Chemistry; Katritzky, A. R.; Rees, C. W., Eds.; Pergamon Press: Oxford, 1984; Vol. 3, pp 657-712. doi:10.1016/B978-008096519-2.00062-X

3. Cacchi, S. J. Organomet. Chem. 1999, 576, 42-64. doi:10.1016/S0022-328X(98)01051-1

4. Keay, B. A. Chem. Soc. Rev. 1999, 28, 209-215. doi:10.1039/a809439j

5. Hou, X. L.; Cheung, H. Y.; Hon, T. Y.; Kwan, P. L.; Lo, T. H.; Tong, S. Y.; Wong, H. N. C. Tetrahedron 1998, 54, 1955-2020. doi:10.1016/S0040-4020(97)10303-9

6. König, B. Hetarenes and Related Ring Systems: Fully Unsaturated Small-Ring Heterocycles and Monocyclic Five-Membered Hetarenes with One Heteroatom. In Houben-Weyl, Methoden der organischen Chemie, 4th ed.; Thieme: Stuttgart, Germany, 2001; Vol. 9, pp 183-286.

7. Brown, R. C. D. Angew. Chem., Int. Ed. 2005, 44, 850-852. doi:10.1002/anie.200461668

8. Fürstner, A. Chem. Soc. Rev. 2009, 38, 3208-3221. doi:10.1039/b816696j

9. Michelet, V.; Toullec, P. Y.; Genêt, J. P. Angew. Chem., Int. Ed. 2008, 47, 4268-4315. doi:10.1002/anie.200701589

10. Jiménez-Núñez, E.; Echavarren, A. M. Chem. Rev. 2008, 108, 3326-3350. doi:10.1021/cr0684319

11. Li, Z.; Brower, C.; He, C. Chem. Rev. 2008, 108, 3239-3265. doi:10.1021/cr068434l
12. Arcadi, A. Chem. Rev. 2008, 108, 3266-3325. doi:10.1021/cr068435d

13. Gorin, D. J.; Sherry, B. D.; Toste, F. D. Chem. Rev. 2008, 108, 3351-3378. doi:10.1021/cr068430g

14. Muzart, J. Tetrahedron 2008, 64, 5815-5849. doi:10.1016/j.tet.2008.04.018

15. Hashmi, A. S. K. Chem. Rev. 2007, 107, 3180-3211. doi:10.1021/cr000436x

16. Fürstner, A.; Davies, P. W. Angew. Chem., Int. Ed. 2007, 46, 3410-3449. doi:10.1002/anie.200604335

17. Zhang, J.; Schmalz, H.-G. Angew. Chem., Int. Ed. 2006, 45, 6704-6707. doi:10.1002/anie.200601252

18. Suhre, M. H.; Reif, M.; Kirsch, S. F. Org. Lett. 2005, 7, 3925-3927. doi:10.1021/ol0514101

19. Praveen, C.; Kiruthiga, P.; Perumal, P. T. Synlett 2009, 1990-1996. doi:10.1055/s-0029-1217517

20. Kim, S.; Kang, D.; Shin, S.; Lee, P. H. Tetrahedron Lett. 2010, 51, 1899-1901. doi:10.1016/j.tetlet.2010.02.026

21. Hashmi, A. S. K.; Schwarz, L.; Choi, J.-H.; Frost, T. M. Angew. Chem., Int. Ed. 2000, 39, 2285-2288. doi:10.1002/1521-3773(20000703)39:13<2285::AID-ANIE2285>3.0.CO ;2-F

22. Dudnik, A. S.; Xia, Y.; Li, Y.; Gevorgyan, V. J. Am. Chem. Soc. 2010, 132, 7645-7655. doi:10.1021/ja910290c

23. Zhou, C.-Y.; Chan, P. W. H.; Che, C.-M. Org. Lett. 2006, 8, 325-328. doi:10.1021/ol052696c

24. Ji, K.-G.; Shu, X.-Z.; Chen, J.; Zhao, S.-C.; Zheng, Z.-J.; Liu, X.-Y.; Liang, Y.-M. Org. Biomol. Chem. 2009, 7, 2501-2505. doi:10.1039/b905332h

25. Shu, X.-Z.; Liu, X.-Y.; Xiao, H.-Q.; Ji, K.-G.; Guo, L.-N.; Qi, C.-Z.; Liang, Y.-M. Adv. Synth. Catal. 2007, 349, 2493-2498. doi:10.1002/adsc.200700319

26. Yao, T.; Zhang, X.; Larock, R. C. J. Org. Chem. 2005, 70, 7679-7685. doi:10.1021/jo0510585

27. Yao, T.; Zhang, X.; Larock, R. C. J. Am. Chem. Soc. 2004, 126, 11164-11165. doi:10.1021/ja0466964

28. Kramer, S.; Madsen, J. L. H.; Rottländer, M.; Skrydstrup, T. Org. Lett. 2010, 12, 2758-2761. doi:10.1021/ol1008685

29. Hashmi, A. S. K.; Sinha, P. Adv. Synth. Catal. 2004, 346, 432-438. doi:10.1002/adsc.200303201

30. Blanc, A.; Alix, A.; Weibel, J.-M.; Pale, P. Eur. J. Org. Chem. 2010, 1644-1647. doi:10.1002/ejoc.200901331

31. Blanc, A.; Tenbrink, K.; Weibel, J.-M.; Pale, P. J. Org. Chem. 2009, 74, 5342-5348. doi:10.1021/jo9008172

32. Liu, Y.; Song, F.; Song, Z.; Liu, M.; Yan, B. Org. Lett. 2005, 7, 5409-5412. doi:10.1021/ol052160r

33. Du, X.; Song, F.; Lu, Y.; Chen, H.; Liu, Y. Tetrahedron 2009, 65, 1839-1845. doi:10.1016/j.tet.2008.11.109

34. Zhang, X.; Lu, Z.; Fu, C.; Ma, S. J. Org. Chem. 2010, 75, 2589-2598. doi:10.1021/jo100146p

35. Belting, V.; Krause, N. Org. Biomol. Chem. 2009, 7, 1221-1225. doi:10.1039/b819704k

36. Aponick, A.; Li, C.-Y.; Malinge, J.; Marques, E. F. Org. Lett. 2009, 11, 4624-4627. doi:10.1021/ol901901m

37. Egi, M.; Azechi, K.; Akai, S. Org. Lett. 2009, 11, 5002-5005. doi:10.1021/ol901942t

38. Marshall, J. A.; Robinson, E. D. J. Org. Chem. 1990, 55, 3450-3451. doi:10.1021/jo00298a012

39. Marshall, J. A.; Sehon, C. A. J. Org. Chem. 1995, 60, 5966-5968. doi:10.1021/jo00123a040 
40. Schwier, T.; Sromek, A. W.; Yap, D. M. L.; Chernyak, D.; Gevorgyan, V. J. Am. Chem. Soc. 2007, 129, 9868-9878. doi:10.1021/ja072446m

41. Yazici, A.; Pyne, S. G. Tetrahedron Lett. 2011, 52, 1398-1400. doi:10.1016/j.tetlet.2011.01.120

42. Hashmi, A. S. K. Angew. Chem., Int. Ed. Engl. 1995, 34, 1581-1583. doi:10.1002/anie.199515811

43. Ma, S. M.; Zhang, J. L.; Lu, L. Chem.-Eur. J. 2003, 9, 2447-2456. doi:10.1002/chem.200204664

44. Fukuda, Y.; Shiragami, H.; Utimoto, K.; Nozaki, H. J. Org. Chem. 1991, 56, 5816-5819. doi:10.1021/jo00020a024

45. Gabriele, B.; Salerno, G.; Lauria, E. J. Org. Chem. 1999, 64, 7687-7692. doi:10.1021/jo990847h

46. Gabriele, B.; Salerno, G.; De Pascali, F.; Costa, M.; Chiusoli, G. P. J. Org. Chem. 1999, 64, 7693-7699. doi:10.1021/jo990848+

47. Gabriele, B.; Salerno, G. Chem. Commun. 1997, 1083-1084. doi:10.1039/a701988b

48. Gabriele, B.; Salerno, G.; De Pascali, F.; Scianò, G. T.; Costa, M.; Chiusoli, G. P. Tetrahedron Lett. 1997, 38, 6877-6880. doi:10.1016/S0040-4039(97)01584-0

49. Bolte, B.; Odabachian, Y.; Gagosz, F. J. Am. Chem. Soc. 2010, 132, 7294-7296. doi:10.1021/ja1020469

50. Dias Jurberg, I.; Odabachian, Y.; Gagosz, F. J. Am. Chem. Soc. 2010, 132, 3543-3552. doi:10.1021/ja9100134

51. Gronnier, C.; Odabachian, Y.; Gagosz, F. Chem. Commun. 2011, 47, 218-220. doi:10.1039/c0cc00033g

52. Istrate, F. M.; Gagosz, F. Org. Lett. 2007, 9, 3181-3184. doi:10.1021/ol0713032

53. Fürstner, A.; Stelzer, F.; Szillat, H. J. Am. Chem. Soc. 2001, 123, 11863-11869. doi:10.1021/ja0109343

54. Fürstner, A.; Szillat, H.; Stelzer, F. J. Am. Chem. Soc. 2000, 122, 6785-6786. doi:10.1021/ja001034+

55. Saito, A.; Konishi, T.; Hanzawa, Y. Org. Lett. 2010, 12, 372-374. doi:10.1021/ol902716n

56. Baskar, B.; Bae, H. J.; An, S. E.; Cheong, J. Y.; Rhee, Y. H.; Duschek, A.; Kirsch, S. F. Org. Lett. 2008, 10, 2605-2607. doi:10.1021/ol8008733

57. Sherry, B. D.; Toste, F. D. J. Am. Chem. Soc. 2004, 126, 15978-15979. doi:10.1021/ja044602k

58. Yeh, M.-C. P.; Pai, H.-F.; Hsiow, C.-Y.; Wang, Y.-R. Organometallics 2010, 29, 160-166. doi:10.1021/om900833k

59. Cheong, J. Y.; Im, D.; Lee, M.; Lim, W.; Rhee, Y. H. J. Org. Chem. 2011, 76, 324-327. doi:10.1021/jo102005x

60. Uemura, M.; Watson, I. D. G.; Katsukawa, M.; Toste, F. D. J. Am. Chem. Soc. 2009, 131, 3464-3465. doi:10.1021/ja900155x

61. Bae, H. J.; Baskar, B.; An, S. E.; Cheong, J. Y.; Thangadurai, D. T.; Hwang, I.-C.; Rhee, Y. H. Angew. Chem., Int. Ed. 2008, 47, 2263-2266. doi:10.1002/anie.200705117

62. Dubé, P.; Toste, F. D. J. Am. Chem. Soc. 2006, 128, 12062-12063. doi:10.1021/ja064209+

63. Williams, D.; Andersen, R. J.; Van Duyne, G. D.; Clardy, J. J. Org. Chem. 1987, 52, 332-335. doi:10.1021/jo00379a002

64. Saeed, M. A.; Sabir, A. W. Fitoterapia 2004, 75, 81-84. doi:10.1016/j.fitote.2003.08.010

65. Tatsimo, S. J. N.; Tane, P.; Srinivas, P. V.; Sondengam, B. L.; Melissa, J.; Okunji, C. O.; Schuster, B. M.; Iwu, M. M.; Khan, I. A. Planta Med. 2005, 71, 1145-1151. doi:10.1055/s-2005-873164

66. Mézailles, N.; Ricard, L.; Gagosz, F. Org. Lett. 2005, 7, 4133-4136. doi:10.1021/ol0515917
67. Within the limits of detection by ${ }^{1} \mathrm{H}$ NMR spectroscopy of the crude reaction mixture.

\section{License and Terms}

This is an Open Access article under the terms of the Creative Commons Attribution License

(http://creativecommons.org/licenses/by/2.0), which permits unrestricted use, distribution, and reproduction in any medium, provided the original work is properly cited.

The license is subject to the Beilstein Journal of Organic Chemistry terms and conditions:

(http://www.beilstein-journals.org/bjoc)

The definitive version of this article is the electronic one which can be found at:

doi:10.3762/bjoc. 7.100 